\title{
Impacts of Climate Changes on Management Policy of the Harbors, Land Areas and Wetlands in the São Paulo State Coastline (Brazil)
}

\section{A. Pezzoli ${ }^{3 *}$, P. Alfredini ${ }^{1}$, E. Arasaki ${ }^{1,2}$, M. Rosso ${ }^{3}$ and W. C. de Sousa Jr. ${ }^{4}$}

${ }^{1}$ Polytechnic School of São Paulo University, Department of Hydraulic and Environmental Engineering, Harbour and Coastal Area of the Hydraulic Laboratory, Avenida Professor Luciano Gualberto, Travessa 3, n. 380, Cidade Universitaria, CEP 05508-010, São Paulo, Brazil

${ }^{2}$ National Institute of Space Research, Av. Dos Astronautas n. 1758, CEP 12227-010, São José dos Campos, São Paulo, Brazil

${ }^{3}$ Polytechnic of Torino, Engineering Faculty, Department of Environment, Land and Infrastructure Engineering, CorsoDucadegli Abruzzi n. 24, 10129, Torino, Italy ${ }^{4}$ Aeronautic Technology Institute, Civil Engineering Division, Department of Water Resources and Environmental Sanitation; PraçaMarechal Eduardo Gomes $n$. 50, Vila das Acacias, CEP 12228-900, São Jose dos Campos, São Paulo, Brazil.

\begin{abstract}
Santosharbor and São Sebastião Oil Maritime Terminal are the most important oil and gas facility in the São Paulo State Coastline. Santosharbor had, in the last decade, increased rapidly the container handling rate, being the first in Latin America. Santos Metropolitan Region is one of the most important of Brazilian Coastline, also considering the tourism. For that great economic growth scenario it is very important to have wave climate and tidal levels well known considering the sea hazards influence in ship operations.

Since the hind-cast just represents the deep water wave climate, to make time-series of the wave's parameters in coastal waters, for evaluation of sea hazards and ship operations, it is necessary to take into account the variations of those parameters in shallow waters with coastal instrumental data. Analysis of long term wave data-base (19572002) generated by a comparison between wave's data modeled by a "deep water model" (ERA40-ECMWF) and measured wave's data in the years $1982-1984$ by a coastal buoy in Santos littoral (São Paulo State, Brazil) was made. Validation checking procedures with instrumental measurements of storm surges made in other years than 1982-1984 shows high level of confidence.

These data, obtained from the climatological analysis compared with a data set found from a scale model of the whole area of Santos Bay, Estuary and nearby beaches (Brazil), showed the impact of maritime climate changes, wave climate and tides upon harbor and coastal structures maintenance, beaches stability, tidal inlet saline intrusion and wetlands flooding.

In the same time, the complex environmental system, that characterized the area included between Santos and Caraguatatuba, generates different natural hazard event affecting the maritime activity. A comparative study about the coastal flooding (Santos area) and the fluvial flooding (Juqueriquerê river) was conducted. An analysis about the sea level rise, the wave climate and the flooding risk as well as the sediment transport was developed.

Considering the increasing of the sea hazards, the high values of the facilities and infrastructures in São Paulo State Coastline, it is necessary to mitigate the risks from the point of view of the harbor and coastal structures maintenance and projects purposes increasing defenses procedures. Hence, based on the results obtained by the Authors in previous researches, are highlighted guidelines strategies suggested for Access Channels dimensions, wharves free-board, jetties and breakwaters dimensions, dredging rates, rigid and flexible littoral defenses, saline intrusion and land protection against flooding (including wetlands).
\end{abstract}

Keywords: Climate change; Geomorphology; Risk assessment; Harbor operations, Waves; Maintenance policy

\section{Introduction}

As well know the climate change affect the human activity, the agriculture and the industry [1] as well as the tourism business [2] However a less bibliography was developed on the effect of the climate change on the maritime navigation. In fact, also if some studies were conducted about the effect of the climate change on the wind conditions and the wave action, the studies about the management and the policies are focused principally about the mitigation of the greenhouse gas emissions (GHG) generate by the navigation $[3,4]$.

Nevertheless it is evident an inadequate bibliography about the effect of the climate change on the maritime navigation. For this reason a less literature is present about the management policy that the Government and the Organizations responsible for the port control can apply to sustain the shipping business due to the climate change effects.

There is the awareness that conditions of bathymetry, tides, winds, currents and waves for next decades shall have climate changes impacts on maritime navigation. The risk is understood, but only in a qualitative way, as composed by Hazard, Exposure and Vulnerability [5].
This paper goal is to overcome the contraposition that it emerges between the defence against the hydraulic risk and the management to preserve the environmental protection for nautical purposes. Moreover, basing on the results obtained by the Authors in the previous published researches, the highlighted guidelines strategies are suggested for access channels dimensions, wharves free-board, jetties and breakwaters dimensions, dredging rates, rigid and flexible littoral defenses, saline intrusion and land protection against flooding (including wetlands).

*Corresponding author: A. Pezzoli, Department of Environment, Land and Infrastructure Engineering, Polytechnic of Torino, Torino, Italy, Tel: (00 39) 3472221638; E-mail: d001937@polito.it

Received January 23, 2013; Accepted March 29, 2013; Published April 11, 2013

Citation: Pezzoli A, Alfredini P, Arasaki E, Rosso M, de Sousa Jr. WC (2013) Impacts of Climate Changes on Management Policy of the Harbors, Land Areas and Wetlands in the São Paulo State Coastline (Brazil). J Climatol Weather Forecasting 1: 101. doi:10.4172/2332-2594.1000101

Copyright: ( 2013 Pezzoli A, et al. This is an open-access article distributed unde the terms of the Creative Commons Attribution License, which permits unrestricted use, distribution, and reproduction in any medium, provided the original author and source are credited. 
The São PauloState (Brazil) Coastline (Figure 1) has around 450 km. The Harbors Areas of Santos and São Sebastião (Figure 2 and 3) concentrates around of $12 \%$ Brazilian international trading of 688 million tons per year and around $26 \%$ of Brazilian international trading of US\$ FOB466million. SantosHarbor is the most important in the Southern Hemisphere and the first in Latin America. São Sebastião Oil Maritime Terminal is the most important Brazilian oil and gas facility. In the last decade important oil and gas reserves were discovered in the SantosOffshoreBasin and São Paulo Coastline received a great demand for supplier boats harbors for the petroleum industry [6]. Santos Metropolitan Urban Region is one of the most important of Brazilian Coastline, also considering the tourism.

For that great economic growth scenario it is very important to have well known the main maritime hydrodynamics forcing processes including climate changes in tidal levels, currents and waves, considering the sea extreme events hazards influence in vessel operations, coastal erosion, land flooding and estuarine mangrove wetlands survival as marine ecosystem [7].

Therefore is essential, due to the differences of the geographic system by a point of view of geomorphology and ecosystem, to analyze the entire area of São Paulo State Coastline. In the same time, as indicate before, this area was divided in two part: Santos and São Sebastião with the Juqueriquerê catchment and waterway.

The first area is affected from the increasing of the storm surges (sea level rise) as well as from the waves generated by the climate change. Instead the second area is influenced by the increasing of frequencies in the storm surges in addition to the flooding risk.

Extending the study at these two different zones, increases the validity of the results proposed in the present research because the phenomena analyzed are different so that the suggested management policies can be applied to a wide number of cases. It is important to note that the geographical system of São Paulo State Coastline have a similarity in the South America in particular in the coastline of the South of the Brazil. For this reason the policies recommended by this research to manage the effect of the climate change on the maritime navigation, can be applied in a large area making the results more general and widely applicable.

It is important to note that the Juqueriquerê Catchment is the major in São Paulo State (Brazil) North Coastline (Figure 4).

The Juqueriquerê Waterway is a $4 \mathrm{~km}$ estuarine channel used by small piers and docks. The entrance bar doesn't have any amelioration

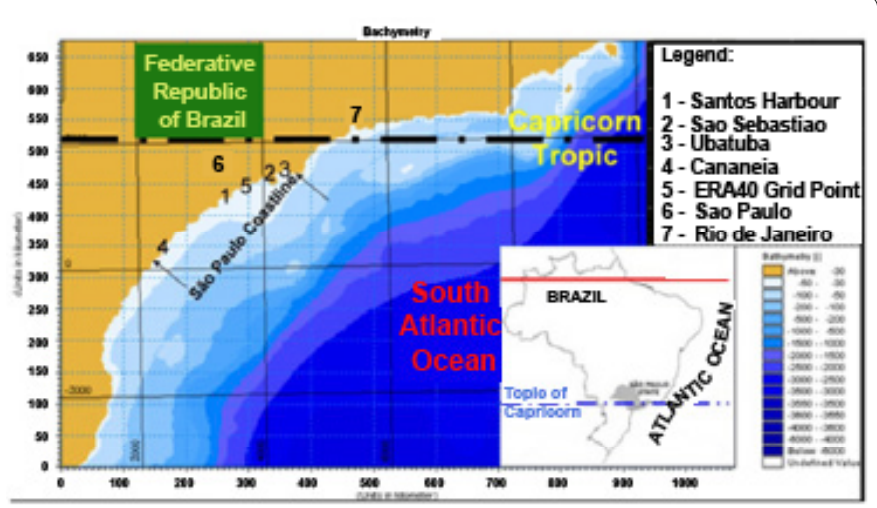

Figure 1: Site location

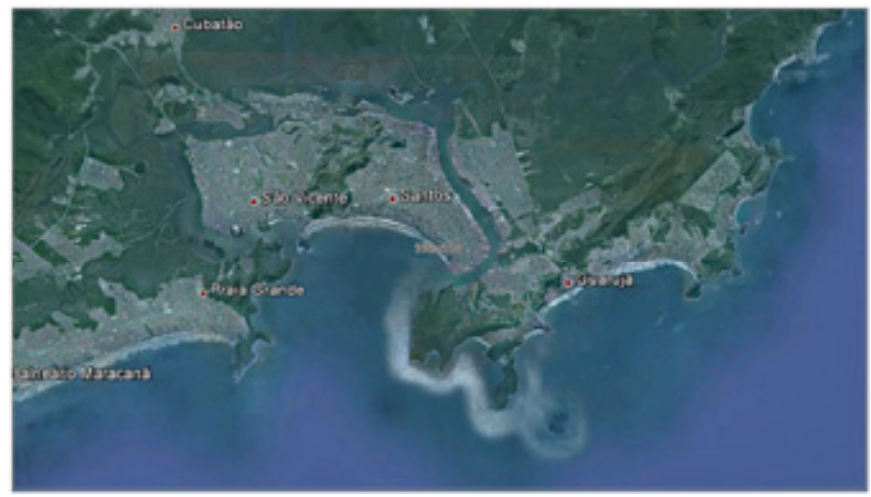

Figure 2: Harbor Area of Santos

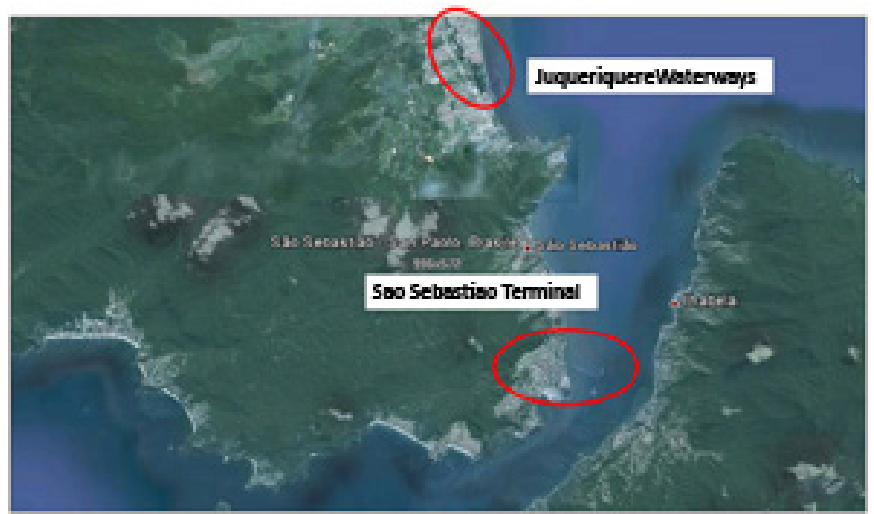

Figure 3: Harbor Area of São Sebastião

works and the boats maneuvers are difficult and dangerous. Example of navigation possibilities in the waterway was the dock operation in the period 1927-1967, the "Fazenda dos Ingleses" (English Farm), has sent the tropical fruits production to England. The railway line of the farm had $120 \mathrm{~km}$, with docks and warehouses in the right bank of the estuary. The Packing House, in the dock area, was considered the second of this type in South America. The cargo boats, more than 20 in the forties decade, had an individual load of 55 dwt. In March 1967, a strong debris-flow, rain more than $600 \mathrm{~mm}$ in 2 days (monsoonal rates), combined with storm surge, caused more than 400 casualties and material losses. After that, the docks were closed [8].

In the last four decades, the nautical purposes of leisure and fishing boats increased in both areas mentioned above. It is important to mention the recent interest as supplier area for the offshore LNG and oil. The plant for the gas treatment is located in the left bank of the river and many of the facility heavy cargo equipment used large barges pushpulled by tugs.

Beyond environmental impacts, the cost of the effective improvements consists to bar jetties calibration where this solution means to talk about costs of $5 \mathrm{M} €$; another possibilities is the permanent maintenance with local dredging works, which costs, in the long term of decades, will be the same.

These examples show as, according to the IPCC forecasting, there is the awareness that conditions of bathymetry, tides, winds, currents and waves for next decades shall have climate changes impacts on the coastal area and in the marine navigation. 
Citation: Pezzoli A, Alfredini P, Arasaki E, Rosso M, de Sousa Jr. WC (2013) Impacts of Climate Changes on Management Policy of the Harbors, Land Areas and Wetlands in the São Paulo State Coastline (Brazil). J Climatol Weather Forecasting 1: 101. doi:10.4172/2332-2594.1000101

\section{Material and Methods}

The IPCC and PIANC recommendations [4], about the study of the impact on the climate change on the maritime navigation, are to focus on the met ocean variables such as wind, waves, sea level and ice.

Although large-scale climatic processes are driven by the oceanatmosphere exchange system, very few studies are available on maritime impacts compared to continental impacts due to shorter data series and fewer human consequences [4].

Some analysis about the increasing of the sea level was conducted by Bindoff et al. [9]. The Authors indicates that the global mean sea level increased at an average rate of about $1.7 \pm 0.5 \mathrm{~mm} /$ year during the twentieth century and that the rate has been slightly higher over the period 1961 to 2003.

In other the climate model prediction elaborated by the IPCC panel [10] shows that the global average rate of rise over the twenty first century will be $25 \mathrm{~mm} /$ year, implying that mean sea level will be $0.2 \div$ $0.5 \mathrm{~m}$ higher in the 2100 than 2000 .

In the same time the waves conditions could be affected by climate changes in a number of aspect. Threnberth et al. [11] reports a statistically significant trend of increasing annual mean and winter mean significant wave height (Hs) for the mid-latitudinal North Atlantic and North Pacific, western subtropical South Atlantic, eastern equatorial Indian Ocean, and the East China and South China Seas. It also reports statistically significant decreases in $\mathrm{H}_{\mathrm{s}}$ for western Pacific tropics, the Tasman Sea and the south Indian Ocean. Similar trends are found for the $99 \%$ extreme $\mathrm{H}_{\mathrm{s}}$ with a maximum increase of winter extreme $\mathrm{H}_{\mathrm{s}}$ of $0.4 \mathrm{~m}$ per decade in the North Atlantic. The worsening of wave conditions in the north-eastern North Atlantic is most likely connected to a northward displacement of the storm tracks, with decreasing wave heights in the southern North Atlantic [12].

Following these indications, it is possible to understand how the regional analysis of the sea level and the wave climate become important as shows by Debernard and Roed [13] and by Sterl et al. [14].

Considering the lack of bibliography and researches developed in this topic in the South Atlantic and in particular along the coastal line of the South of the Brazil, it was activated in 2010 a joint project called "Rede Litoral" (http://www.redelitoral.ita.br/). The Research Unit, based in the São Paulo University - Polytechnic Institute, has the goal of the research focused on the study of wave and tidal level analysis, maritime climate change, navigation's strategy and impact on the coastal defenses along the São Paulo Coastline Harbor Areas (Brazil).

As well indicated in the Introduction, this paper summarizes the research developed by the Research Unit of the São Paulo University [6-8,15-17] concentrating on the management policies.

This study was developed analyzing three different aspects of the problems (sea level, wave climate and sediments transport), apparently distant from each other, but, in fact, coordinated as well shows by the PIANC report [4].

The long term tidal level variability (high tide, mean sea level and low tide) assessment considering the Santos Dock Company (CDS) tidal variability (Highest High Water, Mean Sea Level and Lowest Low Water) for the last six decades, comprising three moon nodal cycles (58 years) shows a consistent response of relative sea level rise. Those figures were of similar magnitude than the other long term tidal series recorded in São Paulo Coastline, at the tidal gauges of Cananeia (1955-
1992), according to Franco et al [18], $200 \mathrm{~km}$ southward, and Ubatuba (1954-2003), $200 \mathrm{~km}$ northward (Figure 1).

Then a scale model of the Santos Bay, estuary with the Santos Harbor (Figure 5) was used to evaluate beach erosion and the land and mangrove wetlands flooding (Figure 6). This model was used to modeling tidal cycles and wave climate in the area nearby beaches of Santos [16]. The sea level data obtained by the simulation with the physic model were used to validate the measured data in the hydrometer of Santos Harbor. The high confidence obtained by this comparison, confirmed the validity of the long term data base used for the analysis of the sea level rise.

Considering the problem generated by the short time that the wave data are recorded by the buoy, an innovative methodology is developed in this research.

A long term wave data-base (1957-2002) was made by a comparison between wave's data modeled by the European deep water data base meteorological model ERA-40 Project [19] and measured wave's data in the years 1982-1984 by a coastal buoy in Santos littoral (São Paulo State,

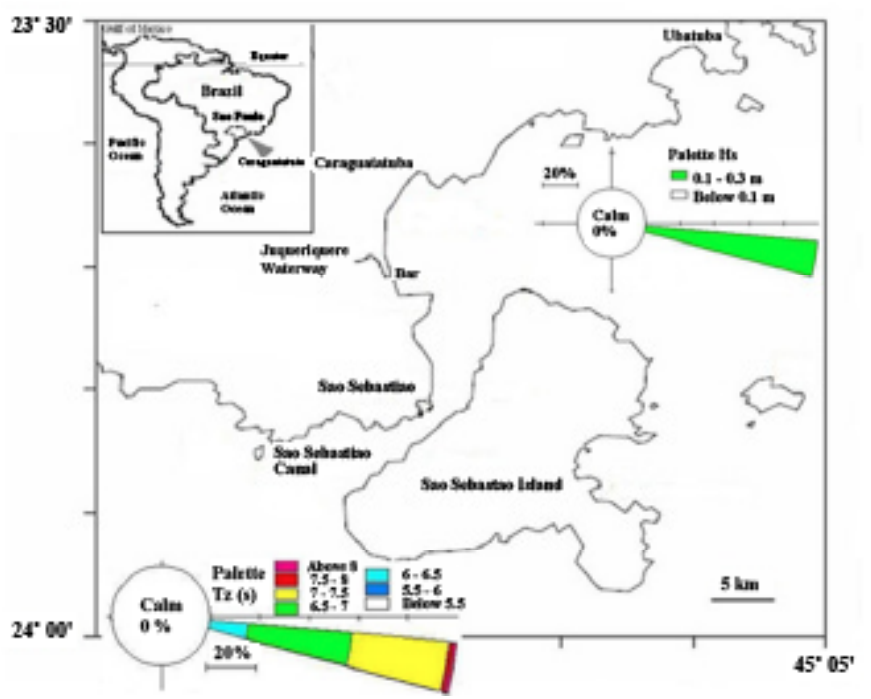

Figure 4: Location map of Juqueriquerê Catchment and Waterway with significant height and average period of local wave roses

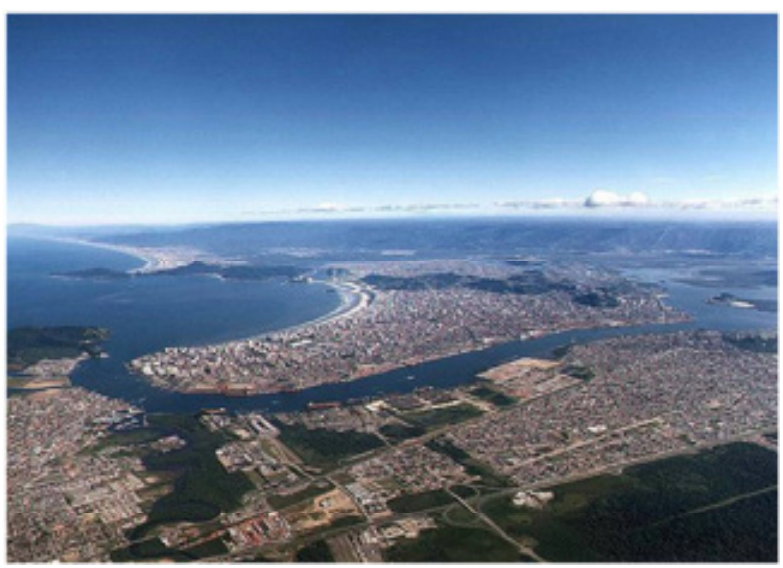

Figure 5: Aerial view of Santos Bay, Estuary and Harbor 
Citation: Pezzoli A, Alfredini P, Arasaki E, Rosso M, de Sousa Jr. WC (2013) Impacts of Climate Changes on Management Policy of the Harbors, Land Areas and Wetlands in the São Paulo State Coastline (Brazil). J Climatol Weather Forecasting 1: 101. doi:10.4172/2332-2594.1000101

Page 4 of 7

Brazil). Calibration coefficients according to angular sectors of wave's direction were obtained by the comparison of the instrument data with the modeled ones, and applied to the original scenarios. Validation checking procedures with instrumental measurements of storm surges made in other years than 1982-1984 shows high level of confidence. Finally the significant height $\left(\mathrm{H}_{\mathrm{s}}\right)$ and the peak period $\left(\mathrm{T}_{\mathrm{p}}\right)$ obtained by the "virtually" data-base (1957-2002) were analyzed to evaluate the possible effect of the climate change on the sea state $[7,15]$.

Finally, as well indicated in the previous paragraph, was studied the Juqueriquerê Catchment with a particular attention at the sediment transport. It has the following main features: area of $430 \mathrm{~km}^{2}$, long term average discharge of $11 \mathrm{~m}^{3} / \mathrm{s}$, heavy rainfall rates (around $3000 \mathrm{~mm} /$ year) producing high fluvial sediment transport, floods and debrisflows. The last ones are due to the steep slopes and the altitude $(\sim 1000$ $\mathrm{m}$ ) of the Serra do Mar mountains near the coast, producing the orographic effect, which rapidly condensates the sea humidity.

The fluvial dynamics is the cause of high solid transport capacity and fluvial and coastal morphology transformations that combined with recurrent and intense flood events, causing riparian and debris-flow on coastal region with important anthropic impact. This event is the cause of extensive risks and damages to population and infrastructures.

Strong debris-flows occur in this region, because events similar to monsoonal rain rates (higher than $300-400 \mathrm{~mm}$ per day) occur in multi decadal periods. The region history records shows this type of strong events in 1859, 1919, 1944 and the last and more catastrophic in March 1967.

\section{Results and Discussion}

As said in the previous paragraph, it is important summarize the results obtained by the Authors in the researches [6-8,15-17] to define the consequences of the climate change for the navigation purpose and the management policy.

Focusing on the tidal and on the sea level rise [6] and according to the CDS tidal gauge, it was possible to have the annual trends for Highest High Water (HHW), Mean Sea Level (MSL) and Lowest Low Water (LLW) (Figure 7), which shows a generalized sea level rise with the following rates in cm/century: 47, 25 and 45, based on data from 1952 till 2007 (3 moon nodal cycles).

The same evaluation was obtained for the last two moon nodal cycles gives: 57,39 and 65 . It means that there is an increasing rate of sea level rise in the last years and it is possible to reach trend rates from 50 to $100 \mathrm{~cm} /$ century in the next decades.

The obtained results about the increasing of the sea level for the São Paulo coastal line are in line with the IPCC scenario [10] as discussed in the Material and Methods paragraph.

According to that scenario, the simulation of scale model showed the flooding of around 50\% of the Santos Estuary mangroves [16] and around $100 \mathrm{~m}$ of the beaches (Figure 8 ), with the corresponding wave scour. Also in the last century, Santos Harbor wharves free-board (150 $\mathrm{cm}$ ) lost around $35 \mathrm{~cm}$.

Moreover, the analysis of the wave climate change on the extreme storm surge wave's conditions, using the calibrated ERA-40 1957-2002 data-base, shows an increasing trend, both in the linear and mobile average with a period of 5 years, in the $\mathrm{H}_{\mathrm{s}}$ and $\mathrm{T}_{\mathrm{p}}$ values and also in the frequency of storm surge events in the last decade (Figures 9 and 10 ). With the mobile average is possible to see the influence of a warm episode of El Niño in The Pacific Ocean waters (1991-1993) enhanced with the huge Pinatubo Volcano eruption in The Philippines and a cold one of La Niña (1973-1976).

In the same time, from the Figure 9 and10, we can see that, in the São Paulo coastal line, the $\mathrm{H}_{\mathrm{s}}$ have an high frequencies of the estimated values above that $0.7 \mathrm{~m}$. Some and residual cases of the storm's events have the value of the $\mathrm{H}_{\mathrm{s}}$ below at $0.7 \mathrm{~m}$ associated with the shortest $\mathrm{T}_{\mathrm{p}}$. The agreement between this evaluation of $\mathrm{H}_{\mathrm{s}}$ and $\mathrm{T}$ in São Paulo costal line with the climate conditions calculated from the measured data for the Juqueriquerê Catchment and Waterway (Figure 4 and 6), confirm the validity of the methods used to build the long-term data base that it well representing the sea state conditions of the São Paulo area.

According to that trend it was possible to forecast an $\mathrm{H}_{\mathrm{s}}$ increasing since 1957 till 2050 from $1.0 \mathrm{~m}$ to $1.4 \mathrm{~m}$, with more than five times the frequency of occurrence of the storm surges since the 1950 and 1960 decades. It is well known that the wave energy per horizontal area and the long shore sand transport in the surf zone of waves is proportional to the square of wave height, meaning an increasing around of $100 \%$ per century. Also according to the classical Hudson's Formula, the rubble mound weight of ripraps, breakwaters and jetties are proportional to $\mathrm{H}_{\mathrm{s}}^{3}$, meaning an increasing of $200 \%$ per century for the new design

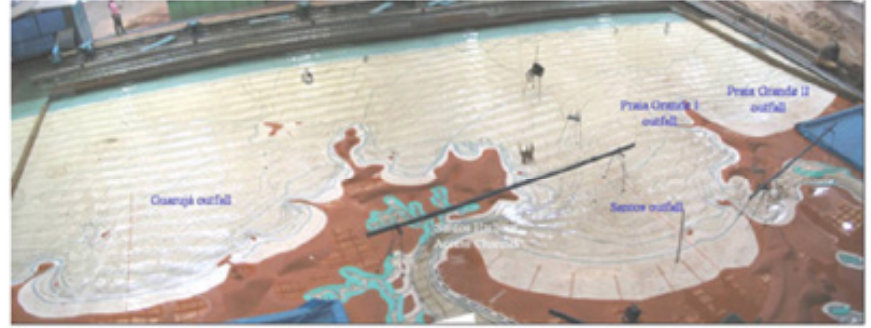

Figure 6: Scale model of Santos Bay, Estuary and Harbor and nearby beaches

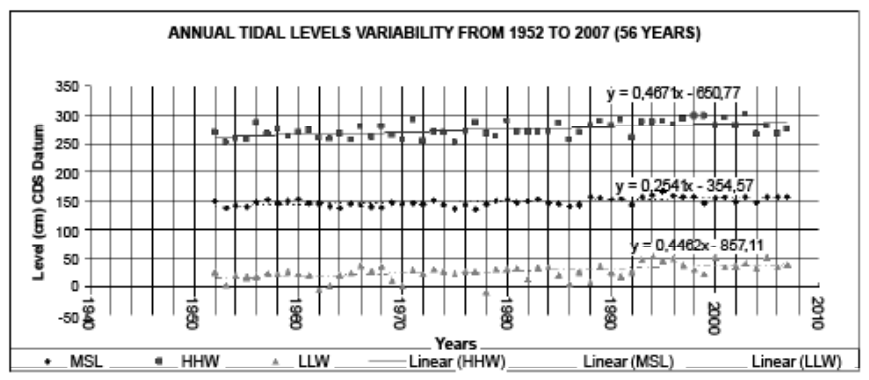

Figure 7: Santos Harbor tidal trends $(1952-2007)$

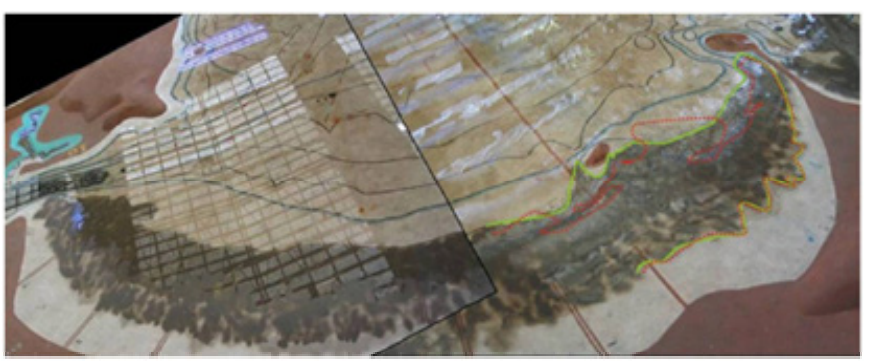

Figure 8: Scale model storm surge test: view of the beach scour 


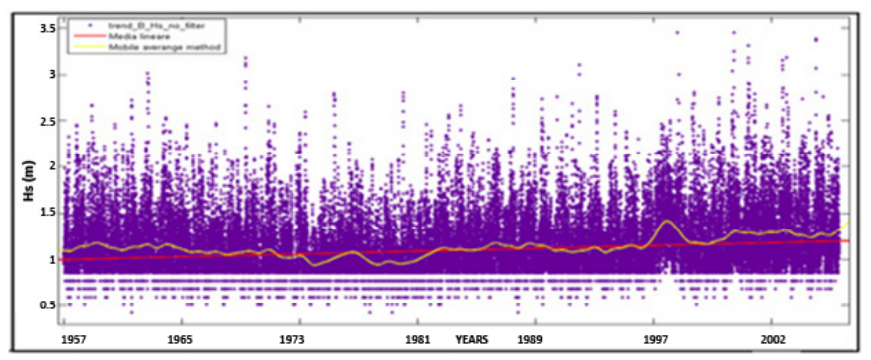

Figure 9: São Paulo Coastline significant wave trend (1957 - 2002)

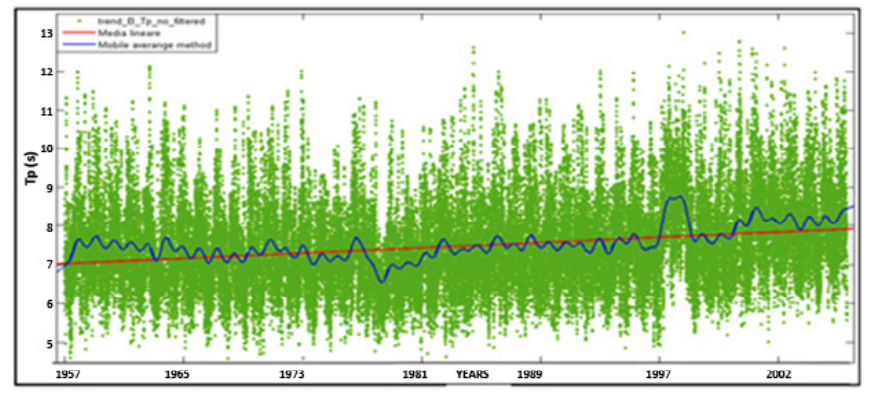

Figure 10: São Paulo Coastline peak period trend (1957-2002)

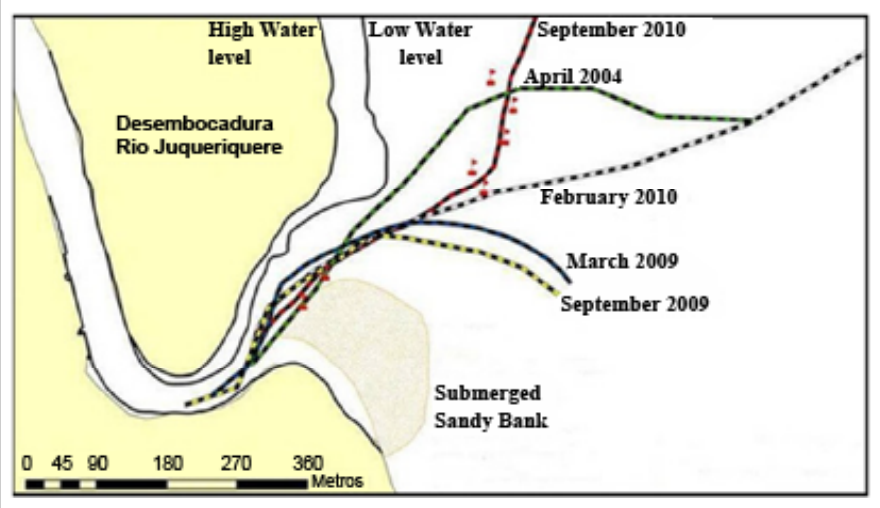

Figure 11: Entrance channel thalweg in rainy (April 2004, March 2009, February 2010) and dry (September 2009 and 2010) season in the Juqueriquerê Waterway

scenario, or an increasing in the damage rate and maintenance costs of those existing structures.

Finally, referring to [6] for what to concern the study and the results about the Juqueriquerê Catchment, it can be summarized that:

- The increasing of the sea level rise is included between 50 to 100 $\mathrm{cm} /$ century in the next decades in agreement with the IPCC scenario [10]

- The increasing of the sea level rise generates a flooding of around $50 \%$ of the Santos Estuary mangroves and around $100 \mathrm{~m}$ of the beaches as well demonstrate by the simulation of the physical model

- The climate change impacts on the increasing of the $\mathrm{H}_{\mathrm{s}}$ for a $0.4 \mathrm{~m}$ in the next 50 years as well as in the peak period of the wave

- These calculated increasing of the significant wave height and of the peak period are in agreement with the wave climate obtained by the measured data for the Juqueriquerê Catchment and Waterway

- In the Juqueriquerê Catchment and Waterway, the composite effect of the increasing of the significant height of the wave with the increasing of the storm and the associated flooding, generates the channel thalweg (Figure 11)

- The increasing of the significant wave height generates a possible increasing of $200 \%$ per century for the new design scenario in the harbor's structures

This analysis confirmed how the system is to be considered as a complex system where the effects on the channel, breakwater and harbor structures are generated by sea level rise, the wave climate and the flooding jointly with the sediment transport.

The consequences for navigation purposes, considering depths and channel widths are very complex and are summarized in Figure 12 elaborated considering the obtained results and the related assumptions.

As an example of some possible structural solution, it can be referred at the cost-benefit structural solution to reduce dredging costs in the Santos Access Channel proposed by Arasaki and Alfredini [20] and by Alfredini et al. [21]. The Authors proposed a solution with jetties in the Santos Access Channel which will reduce present maintenance dredging rates and will produce beach enlargement (Figure 13).

\section{Conclusions}

The paper summarizes ten years of research about the impact of maritime climate changes in the São Paulo State Coastline, developed by the Authors mainly in the Santos area, where there is the major amount of hydrodynamics data. It was possible to reach the goal of quantifying the magnitude order of tides and wave changes and to correlate them with the impact on maritime structures and the proposed mitigatory measures and structures.

Based on the quantitative assessment made it is possible to present the following and innovative strategic plan and the maintenance policy focusing on the navigation and coastal defenses for São Paulo State Coastline:

\begin{tabular}{|c|c|c|}
\hline & Protection & $\begin{array}{l}\text { - Wetlands restoration } \\
\text { - Shoreline enhancement and land } \\
\text { preservation } \\
\text { Jetties, seawalls, dikes construction/ } \\
\text { upgrades against higher design waves and } \\
\text { to } 1 \mathrm{~m} \text { of relative sea level rise }\end{array}$ \\
\hline 2. & Resistance and Resiliency & $\begin{array}{l}\text { - Life cycle upgrades: } 1 \mathrm{~m} \text { higher elevation } \\
\text { of quays } \\
\text { - Increasing the external access channel } \\
\text { width } \\
\text { - Increasing maintenance dredging and } \\
\text { capital dredging to enlarge external } \\
\text { channels and for milder bank slopes }\end{array}$ \\
\hline 3. & System Management & $\begin{array}{l}\text { Focus investments on lower-risk assets } \\
\text { and shift operations away from higher risk } \\
\text { assets }\end{array}$ \\
\hline & Impact Management & $\begin{array}{l}\text { - "Green Port" to manage emissions and } \\
\text { other impacts }\end{array}$ \\
\hline 5. & $\begin{array}{l}\text { Information and } \\
\text { Coordination }\end{array}$ & $\begin{array}{l}\text { Develop information to support consistent } \\
\text { risk assessment, best practice responses, } \\
\text { and necessary partnerships between ports } \\
\text { and their host regions }\end{array}$ \\
\hline
\end{tabular}

Considering the awareness about the importance of climate changes impacts in a coastal area prone to extreme flood and erosion events, 


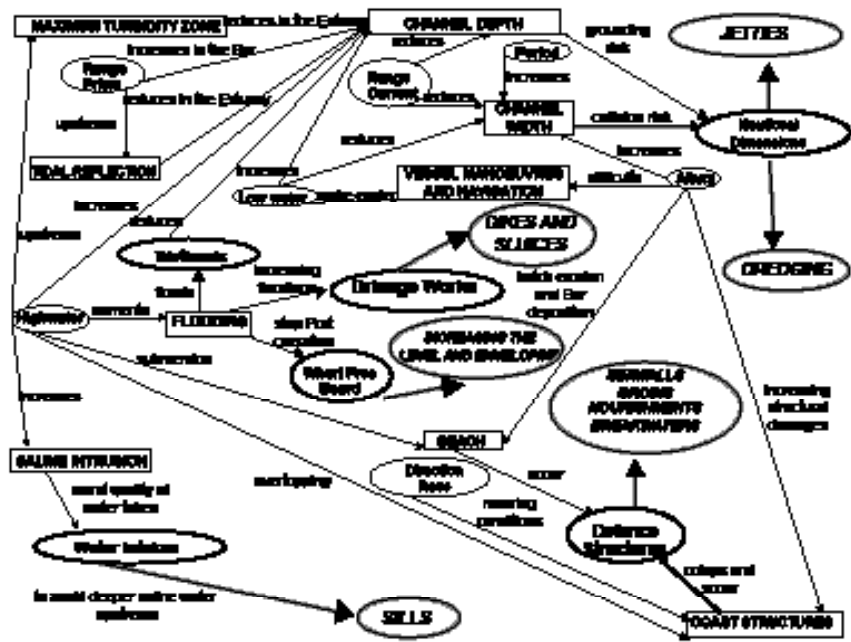

Figure 12: Frame of Santos tidal and wave changes impacts on maritime structures and possible mitigatory works

important issues to support confidence, or not, to activate structural and rigid solution (i.e. two jetties as shows in Figure 13), maintenance dredging (flexible solution), or non-intervention in the waterway are:

-1. There is an overall sea level rising trend.

2. LLW has the highest rate of linear tidal rising.

3. There is an overall tidal range reduction.

4. The tidal prism will change, and the tidal currents velocity should increase, if the HHW levels will drown large fluvial areas, compensating the velocity reduction due to the tidal range decreasing.

5. Considering the issues above, the bar depth should increase.

6. The overall rise of the sea will produce more coastal erosion and littoral drift, in opposition to the outcome of issue 5 .

- It is possible to observe a general significant height and average period wave increasing for annual averaged figures over than $1.5 \mathrm{~m}$ and $8.0 \mathrm{~s}$ (Figure 9 and 10), and the corresponding decadal maximum waves. It means increasing swell. Hence, should be a trend to increase littoral drift, reducing bar depth.

In other, merging the results of the climatological analysis with the result of the physical model, it is possible to made other assumption about the management policies of the São Paulo harbor area and of the Juqueriquerê Catchment and Waterway [6]:

- There are some areas of mud, which may be fluid and sufficient to consider the nautical bottom concept [19], in practice for mud density lower than $1250 \mathrm{~kg} / \mathrm{m} 3$. In these cases it is possible to reduce the under keel clearance. The analysis of September 2010 and March 2011 survey, with detailed samples of the bar and bathymetry should provide confidence for this answer.

- About the thalweg shifting migration (Figure 11), it is possible to conclude:

1. Like for the monsoon weather, the main channel alignment depends upon flood periods, according to rain rate;

2. The shifting between two adjacent thalwegs may be produced by extreme river flow conditions, or a storm surge.

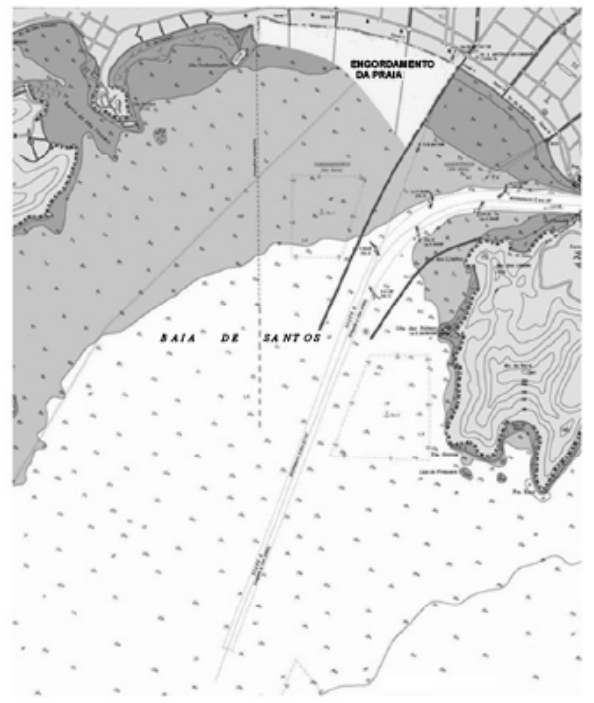

Figure 13: Jetties in Santos Access Channel

Awareness with climate changes impacts importance for the intervention's plan must be considered to obtain a final balanced solution among structures, dredging and non-structural measures for nautical master plan.

It is important to recognize that great natural events are not avoidable, but great disasters are, as the ancient Greek Aristotle (384322 B.C.) said, "It is probable that the improbable will happen" [5].

\section{References}

1. Oliver JE, Hidore JJ, Snow M, Snow R (2010) Climatology: an atmospheric science. Ed Prentice Hall USA 408

2. Jenkins K, Nicholls S (2010) The impacts of climate variability and potentia climate change on tourism business in Torbay, England implications for adaptation. Tourism Analysis 15: 17-30.

3. Den Elzen MGJ, Olivier JGJ, Berk MM (2007) An analysis of options for including international aviation and marine emissions in a post-2012 climate mitigation regime. Netherlands Environmental Assessment Agency (MNP), $\mathrm{AH}$ Bilthoven, the Netherlands.

4. AA. VV (2009) Waterborne transport, ports and waterways: a review of climate change drivers, impacts, responses and mitigation. In: Final Report of the EnviCom-Task Group 3, PIANC, and Brussels, Belgium.

5. Kron W (2008) Coasts-The riskiest places on Earth. Proceeding of the $31^{\text {st }}$ International Conference on Coastal Engineering.

6. Arasaki E, Alfredini P, Pezzoli A, Rosso M (2011) Chapter 17: Coastal area prone to extreme flood and erosion events induced by climate changes: study case of Juqueriquerê River Bar navigation, Caraguatatuba (São Paulo State), Brazil. In: Human Resources and Crew Management, CRC Press/Balkema Book, London.

7. Alfredini P, Pezzoli A, Cristofori El, Dovetta A, Arasaki E (2012) Wave and tida level analysis, maritime climate change, navigation's strategy and impact on the costal defences - Study case of São Paulo State Coastline Harbour Areas (Brazil). Geophysical Research Abstracts 14: 10735

8. Arasaki E (2010) Capacidade de adaptação às mudanças climáticas globais: uma abordagem institucional para a gestão de recursos hídricos. São José dos Campos: Instituto Tecnológico de Aeronáutica, Post Doc Thesis.

9. Bindoff NL, Willebrand J, Artale V, Cazenave A, Gregory J et al. (2007) Observations: Oceanic Climate Change and sea level. In "Climate Change 2007: The Physical Science Basis. Contribution of Working Group I to the Fourth Assessment Report of the Intergovernmental Panel on Climate Change" - Eds. Solom S, Qin D, Manning M, Chen Z, Marquis M, Averyt KB, Tignor M, Miller HL, Cambridge University Press, New York, USA 
Citation: Pezzoli A, Alfredini P, Arasaki E, Rosso M, de Sousa Jr. WC (2013) Impacts of Climate Changes on Management Policy of the Harbors, Land Areas and Wetlands in the São Paulo State Coastline (Brazil). J Climatol Weather Forecasting 1: 101. doi:10.4172/2332-2594.1000101

10. Intergovernmental Panel on Climate Change (2007). Summary for policymakers. In "Climate Change 2007: The Physical Science Basis. Contribution of Working Group I to the Fourth Assessment Report of the Intergovernmental Panel on Climate Change" - Eds. Solom S, Qin D, Manning M, Chen Z, Marquis M, Averyt KB, Tignor M, Miller HL, Cambridge University Press, New Yourk USA.

11. Solom S, Qin D, Manning M, Chen Z, Marquis M et al. (2007) Climate Change 2007: The Physical Science Basis. Contribution of Working Group I to the Fourth Assessment Report of the Intergovernmental Panel on Climate Change. Eds Cambridge University Press, New York, USA.

12. Intergovernmental Panel on Climate Change Solom S, Qin D, Manning M, Chen Z, Marquis M et al. (2007) Climate Change 2007: The Physical Sciences Basis Contribution of Working Group I to the Fourth Assessment Report of the Intergovernmental Panel on Climate Change. Eds Cambridge University Press, New York, USA.

13. Debernard JB, Roed LP (2008) Future wind, wave and storm surge climate in the Northern Seas: a revisit. Tellus A 60: 472-438.

14. Sterl A, van de Brink $H$, de Vries $H$, Haarsma R, van Meijgard E (2009) An ensemble study of extreme storm surge related to water levels in the North Sea in a changing climate. Ocean Sci 5: 369-378.
15. Dovetta A (2012) Analisi dell'influenza dei cambiamenti climatici sul moto ondoso: applicazione alla zona costiera dello Stato del São Paulo (Brasile) Torino: Politecnico di Torino, MSc Thesis

16. Arasaki E, Alfredini P, Gireli TZ (2008) Greenhouse effect and sea level impacts on Santos Estuary and Bay (Brazil) - Physical model study. Proceeding of the COASTLAB08-IAHR.

17. Alfredini P, Arasaki E, Pezzoli A, de Sousa WC Jr (2013) Impact of maritime climate changes on the harbor, land areas, and wetlands of Sao Paulo coastline (Brazil). In: $6^{\text {th }}$ International Perspective on Water Resource and the Environment - IPWE 2013, January 7-9, 2013, Izmir (Turkey).

18. Franco AS, Kjerfve B, Neves CF (2007) A análise de registros de maré extremamente longos. In: Pesquisa Naval n¹9, Estado-Maior da Armada.

19. European Centre for Medium-Range Weather Forecasts (2003) ERA-40 Project. ECMWF, Reading.

20. Arasaki E, Alfredini P (2009) Obras e Gestao de Portos e Costas - A Tecnica Aliada ao Enforque Logistico e Ambiental (2nd Ed). Ed: Edgard Blucher, Sao Paolo, Brazil, ISBN: 9788521204862.

21. AA.VV. (1997) Approach channels - a guide for design. In: Final Report of the Joint Working Group II-30 PIANC-IAPH in cooperation with IMPA and IALA Brussels (Belgium) and Tokyo (Japan).
Citation: Pezzoli A, Alfredini P, Arasaki E, Rosso M, de Sousa Jr. WC (2013) Impacts of Climate Changes on Management Policy of the Harbors, Land Areas and Wetlands in the São Paulo State Coastline (Brazil). J Climatol Weather Forecasting 1: 101. doi:10.4172/2332-2594.1000101 